\title{
SOCIO-SPATIAL POLARISATION IN ZAGREB
}

\author{
Vedran Prelogović \\ University of Zagreb, Faculty of Science, Department of Geography, \\ Mruličev trg 19, Zagreb, Croatia \\ e-mail:vprelogo@geog.pmf.hr;vprelogo@inet.hr
}

\begin{abstract}
The paper is based on the preliminary results of the research of socio-spatial structure in Zagreb. The main socioeconomic indicators: educational structure, average earnings, and the structure of employed and unemployed population were analysed. Despite the lack of relevant statistical indicators, results show notable changes of socio-spatial structure induced by transition processes. Differences between city districts, expressed by socioeconomic indicators can be viewed as a beginning of the process of socio-spatial polarisation in Zagreb.
\end{abstract}

Key words: socio-spatial polarisation, City of Zagreb, city districts, educational structure, earnings, employment, unemployment

\section{INTRODUCTION}

Postsocialist cities of Central and Eastern Europe entered the phase of transition. Process of transition from planned to market economy had significant influence on economic, political and social structures. Significant aspect of these changes is emphasised in socio-spatial structure of the cities. After 1990 the following features mark the postsocialist cities: increase of unemployment, more pronounced social divisions, the share of rich and poor is rising and the zones of social exclusions are spreading.

Differences in socio-spatial structure, especially in the last twenty years or so, are in focus of geographical interest. The interest is mostly revealed in the works of American and West-European researchers, and after the fall of communism and changes that followed, significant attention has been paid by scientists from Central and Eastern Europe. The thesis of polarisation in cities was introduced by Saskia Sassen and the group of American social scientists. Sassen's (2001) starting point is that social polarisation, both of income and in occupation, is a direct consequence of shift from manufacturing to service-based economy. The polarisation has been firstly observed in countries of advanced capitalist economies, mostly in the so-called global cities. The main manifestation of social polarisation 
is rise of upper and lower social classes and shrinking of the middle class. Sassen (2001) emphasises the three main elements which contribute to polarisation: rise of services and decrease of manufacturing activities, rise of high and low paid jobs and informatisation of manufacturing activities. Many researches in world (Clark \& McNicholas, 1996; Andersen et al., 2000; Andersen, 2002) confirmed this, but also pointed out to the complexity of this phenomenon (Woodward, 1995; Hamnett, 1998). Because of differences in the political, economic and social context under which social-spatial structure is changed in American and Westerneuropean cities, some of the hypotheses were re-examined or even rejected. This particularly concerns the rising number of lower social classes or so called emergence of the new urban poverty, which has been proved only in some global cities (Woodward, 1995; Badcock, 1997; Hamnett, 1998; Hamnett, 2001; Hamnet \& Cross, 1998).

As it was already emphasised before, changes in the socio-spatial structure are significant feature of postsocialist cities at the turn of millennium. Until late 1980's/early 1990's the socio-spatial structure was relatively homogeneous (Sykora 1999; Rebernik, 2002). Political changes and introduction of market economy had significant influence on the rise of social differentiations (Sykora, 1999; Kostynskiy, 2001). Unemployment, poverty and rising socio-spatial polarisation are some of the key features of contemporary development of the socio-spatial structure of cities in postsocialist countries (Węcławowicz, 1997; Wießner, 1997; Sykora, 1999; Kostynskiy, 2001).

The process of socio-spatial polarisation has not jet been researched in Croatia. Outgoing research deals with the changes of socio-spatial structure of Zagreb in the period before transition (until 1990's). Findings are related to those of socialist cities before the period of transition. Marinović-Uzelac (1978) emphasises that the socio-spatial structure of Zagreb in 1970's is reflection of the pre-war period (before 1945), which is characterised by prominent differences between social classes, and efforts of communist authorities to dimminish them. Bašić (1994a; 1994b) argues that in period before 1980's there is larger presence of social differentiation according to socioeconomic and family status. The socio-spatial structure of Zagreb is relative homogeneous compared to the cities in Western Europe.

\section{AIM AND METHODOLOGICAL REMARKS}

The paper is based on the preliminary results of the research of socio-spatial structure of Zagreb which has been done for the project "Urban system of Republic of Croatia". The starting point is that in the last twenty years Zagreb's socio-spatial structure has been changed. Changes are induced with the transition from the planned to market economy. In the paper the following questions are examined:

- what is the socio-spatial structure of Zagreb today (i.e. in the period of transition),

- did transition processes contribute to the emergence of the socio-spatial polarisation in the city and

- Are there any relations to the cities of Central and Eastern Europe? 
The analysis of socio-spatial polarisation is based on statistical data from the census of 2001. The major problems in analysis are: changed methodology of the census, changes in the administrative-territorial organisation of Zagreb and spatial level of published statistical data. All censuses after the World War II were done after the principle of de iure population, but the census of 2001 was held after the principle of de facto population. Until 1990 the present territory of the City of Zagreb was organised in 11 city municipalities, and from 1997 the City is constituted in 17 city districts. This makes any comparisons between the census data very difficult and even impossible. Because of that, and due to a better representation, census data of 2001 were used, and in some cases where certain kind of comparison is possible, the data from 1981, 1991 were used together with the results of previous research (Vresk, 1986; Bašić, 1994a, 1994b).

The analysis of socio-spatial polarisation is done for the administrative-territorial unit of the City of Zagreb. The level of analysis is 17 city districts, because they are the lowest spatial level for which the statistical data is available and published. An inadequacy of statistical data on lower level enables us to make more realistic view of changes and the present situation in socio-spatial structure of Zagreb. For purposes of the paper the following socioeconomic indicators are used in the analysis: level of education, average monthly net ear-nings, structure of employed persons and unemployed population. It is assumed that menti-oned socioeconomic indicators are the best representatives of changes in sociospatial struc-ture and that the largest aberrations between different groups of population are expected to be marked by them. It is important to stress that 17 city districts include two urban settle-ments: Zagreb and Sesvete, and 68 smaller urbanised or rural settlements (no one with more than 3000 inhabitants) in the periurban fringe. According to the last census the City of Zagreb has 779145 inhabitants. Most of the population is located in Zagreb 691 $724(88,6 \%)$ and in Sesvete $44914(5,6 \%)$. Other settlements have $42507(5,8 \%)$ inhabitants. This means that almost $95 \%$ of population is situated in the more or less compact urban areas of Zagreb and Sesvete. The remaining 5-6\% of population will not have significant influence on the final results of research.

Transformation of socioeconomic status - Going towards socio-spatial polarisation? Educational structure. Many researches in the world confirmed that employment, education and income are the best indicators of socioeconomic status, with high degree of mutual correlation (Knox \& Pinch, 2000). From mentioned indicators the first one that will be analysed are those for education. Data includes population who had 15 or more years in the time of census. With comparison of data at the urban level, which is, as it was emphasised, not completely comparable, from 1981, 1991 and 2001 there are significant improvements of educational structure (Table 1). The number of those with no school and with uncompleted elementary has decreased and those with secondary school, nonuniversity college and university education had risen. Improvement of this structure can be explained with the general higher standard of education, by the decrease of immigration from rural areas of Croatia and former Yugoslavia (especially from Bosnia and Herzegovina), which in the past had significantly determined educational structure, and in some city districts with intra-urban migrations (young, middle class families with higher level of education tend to move on the fringe of the city into newly build real estates). 
Table 1: Population aged 15 and over by educational attainment in City of Zagreb 1981-2001

\begin{tabular}{|l|r|r|r|r|r|r|}
\hline Year & 1981 & $\%$ & 1991 & $\%$ & 2001 & $\%$ \\
\hline $\begin{array}{l}\text { No school and } \\
\text { unfinfihed elemetary }\end{array}$ & 145084 & 24,9 & 91731 & 14,5 & 56969 & 8,6 \\
\hline Elemetary school & 103869 & 17,8 & 131686 & 20,7 & 106829 & 16,3 \\
\hline Secondary school & 244099 & 41,9 & 285891 & 45,0 & 341344 & 52,0 \\
\hline Non-uni. college & 23242 & 4,0 & 35861 & 5,6 & 38157 & 5,8 \\
\hline Uni. Education & 58372 & 10,0 & 81847 & 12,9 & 109323 & 16,7 \\
\hline Unknown & 7287 & 1,2 & 8413 & 1,3 & 3560 & 0,6 \\
\hline Total & 581953 & 100,0 & 635429 & 100,0 & 656182 & 100,0 \\
\hline
\end{tabular}

Source: Population Census 1981, Statistical Yearbook of Zagreb 1991, Statistical Yearbook of City of Zagreb 2002

Data of 1981 and 1991 refers to the present territorial organisation of City of Zagreb

Educational structure of the city districts shows a heterogeneous pattern (Figs. 1 and 2). The largest differences are in the extreme categories. The share of population with no school and with uncompleted elementary is ranging from 3,8\% in the Gornji grad-Medveščak district, to $13 \%$ in Donja Dubrava, $15 \%$ in Sesvete, and to an almost $23 \%$ in Brezovica (these are the districts which include larger number of urbanized and rural settlements in periurban fringe). Educational level is decreasing from the centre of the city. Districts with the largest share of university educated people have the least of those with the lowest education and vice versa, which is also the evidence of their internal homogeneity (Figures $1 \& 2)$

The best educational structure is in the districts of the central part of the city (Donji grad and Gornji grad-Medveščak) with better housing standards. These parts are traditionally settled with the higher status population, living in the villas and housing buildings built for the middle class on the beginning and in the first part of the $20^{\text {th }}$ century. Areas with heterogeneous educational structure were built mostly in the second part of $20^{\text {th }}$ century in reconstructed parts of the city. They also include newly build real estates in late 1980 's and 1990's. The worst educational structure is in part of the city with lower housing standards which includes houses of illegal building and real estates from 1950's and 1960's that are facing physical and social degradation.

Educational structure of the City of Zagreb has relatively symmetrical concentric pattern. The results of the analysis are in relation to the ones before the transition period (Bašić, 1994) and to some cases in the postsocialist countries (Sykora 1999; Rebernik, 2002).

Earnings of population. Very important indicator of socioeconomic status is earnings. Unfortunately official statistics does not have data for income distribution and structure, which is much better indicator of social differences. In this case the data for average net monthly earnings will be used. Differences according to economic sector and education will be presented on the city level. For the city districts values are estimated and given in relative numbers. Average gross net monthly earnings have some shortcomings. They only show 
differences inside the contingent of employed population. The unemployed and people with social welfare benefits, pensioners etc. are therefore excluded.

Figure 1: Spatial distribution of university educated in city districts of City of Zagreb in 2001

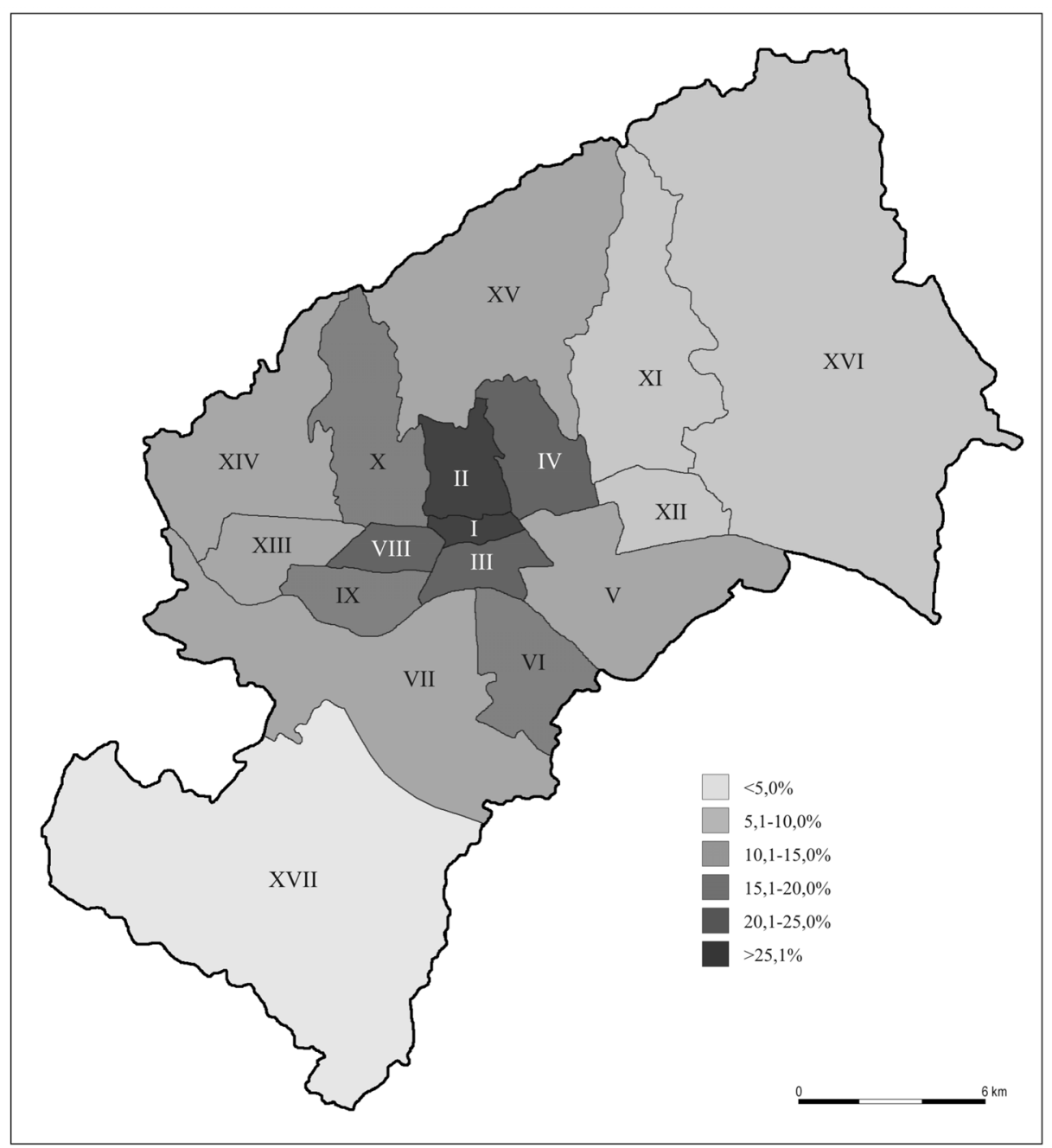

(I Donji grad, II Gornji grad-Medveščak, III Trnje, IV Maksimir, V Pečćenica-Žitnjak, VI Novi Zagrebistok, VII Novi Zagreb-zapad, VIII Trešnjevka-sjever, IX Trešnjevka-jug, X Črnomerc, XI Gornja Dubrava, XII Donja Dubrava, XIII Stenjevec, XIV Podused-Vrapče, XV Podsljeme, XVI Sesvete, XVII Brezovica)

Researches of postsocialist cities show, that from the beginning of transition period there is a significant differentiation according to earnings (Sykora, 1999). Differences between earnings can be marked as the main cause for the emergence of socio-spatial polarisation. It is assumed that after the introduction of market economy the differences between highest 
and lowest earnings are also growing in Zagreb. They are prominent between different sectors of economy and level of education (Table 2 and 3 )

Figure 2: Spatial distribution of population with no-school and unfinished elementary education in city districts of City of Zagreb in 2001

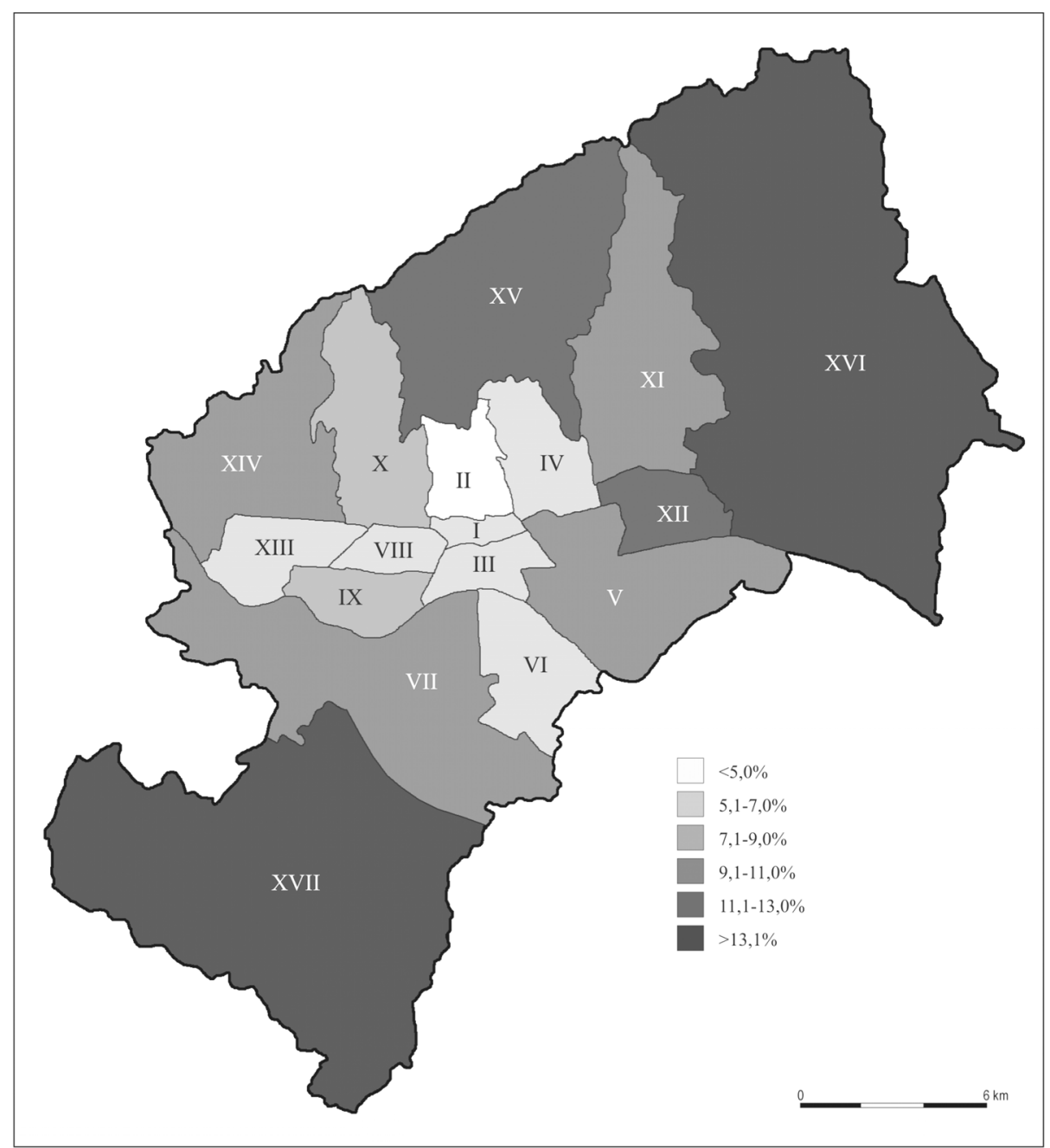

(I Donji grad, II Gornji grad-Medveščak, III Trnje, IV Maksimir, V Pečćenica-Žitnjak, VI Novi Zagrebistok, VII Novi Zagreb-zapad, VIII Trešnjevka-sjevr, IX Trešnjevka-jug, X Črnomerc, XI Gornja Dubrava, XII Donja Dubrava, XIII Stenjevec, XIV Podused-Vrapče, XV Podsljeme, XVI Sesvete, XVII Brezovica)

The highest average earnings have the employed in financial sector. It is $51 \%$ higher than average. This finding is in accordance with the essence of the theory of social polarisation, after which employed in service sector, especially those in financial businesses, have above 
average earnings. On the other side of distribution are those employed in construction whose average earnings are $24 \%$ below average. Average net earnings according to education show even larger differences from the average. Those with university education have $50 \%$ higher, and those with low have around $40 \%$ lower earnings.

Table 2: Average gross monthly earnings of employees in selected sectors of economy in City of Zagreb in 2001

\begin{tabular}{|l|c|c|}
\hline Economy sector & $\begin{array}{c}\text { Gross monthly } \\
\text { earnings in HRK }\end{array}$ & Ratio to average \\
\hline Financial intermediation & 6225 & 151,17 \\
\hline Public administration & 4468 & 108,50 \\
\hline Transport and comminication & 4445 & 107,94 \\
\hline Real estate, renting and other bussines services & 4396 & 106,75 \\
\hline Health & 4360 & 105,88 \\
\hline Manufacturing & 4045 & 98,23 \\
\hline Other public and social services & 3960 & 96,16 \\
\hline Education & 3949 & 95,90 \\
\hline Retail & 3395 & 82,44 \\
\hline Hotels and restaurants & 3290 & 79,89 \\
\hline Construction & 3129 & 75,98 \\
\hline Average & 4118 & 100,00 \\
\hline
\end{tabular}

Source: Statistical Yearbook of City of Zagreb 2002

Earnings given in Croatian kunas (HRK)

Table 3: Average gross monthly earnings of employees in City of Zagreb according to attained education in 2001

\begin{tabular}{|l|c|c|}
\hline Educational attainment and qualificational level & $\begin{array}{c}\text { Gross monthly } \\
\text { earnings in HRK }\end{array}$ & Ratio to average \\
\hline University & 6276 & 152,40 \\
\hline Non-uni. college & 4575 & 111,10 \\
\hline Secondary school & 3735 & 90,70 \\
\hline No school, unfinished elemntary & 2838 & 68,92 \\
\hline High skilled workers & 3957 & 96,09 \\
\hline Skilled workers & 3169 & 76,95 \\
\hline Semi-skilled workers & 2824 & 68,58 \\
\hline Non-sklilled workers & 2558 & 62,12 \\
\hline Average & 4118 & 100,00 \\
\hline
\end{tabular}

Source: Statistical Yearbook of City of Zagreb 2002

Earnings given in Croatian kunas (HRK) 
What is the spatial distribution of earnings? Do any districts stand out of average? If yes, how many and which are they? The absolute figures on earnings are at the present not available for the city districts. To have a clearer picture on differences between districts, the values were estimated according to average of monthly earnings in City of Zagreb and educational attainment of employees in city districts (Figure 3). It is clear that the highest positive stand out is in the city centre (Gornji grad-Medveščak 15,5\%, Donji grad 12,7\%) and the negative in the peripheral parts of the city (Donja Dubrava $-10,4 \%$, Sesvete $-11,7 \%$ and Brezovica $-14,7 \%$ ). In other districts, differences are not so prominent. It is assumed that differences are much larger at lower levels.

Figure 3: Estimated relative values of earnings in city districts of City of Zagreb in 2001

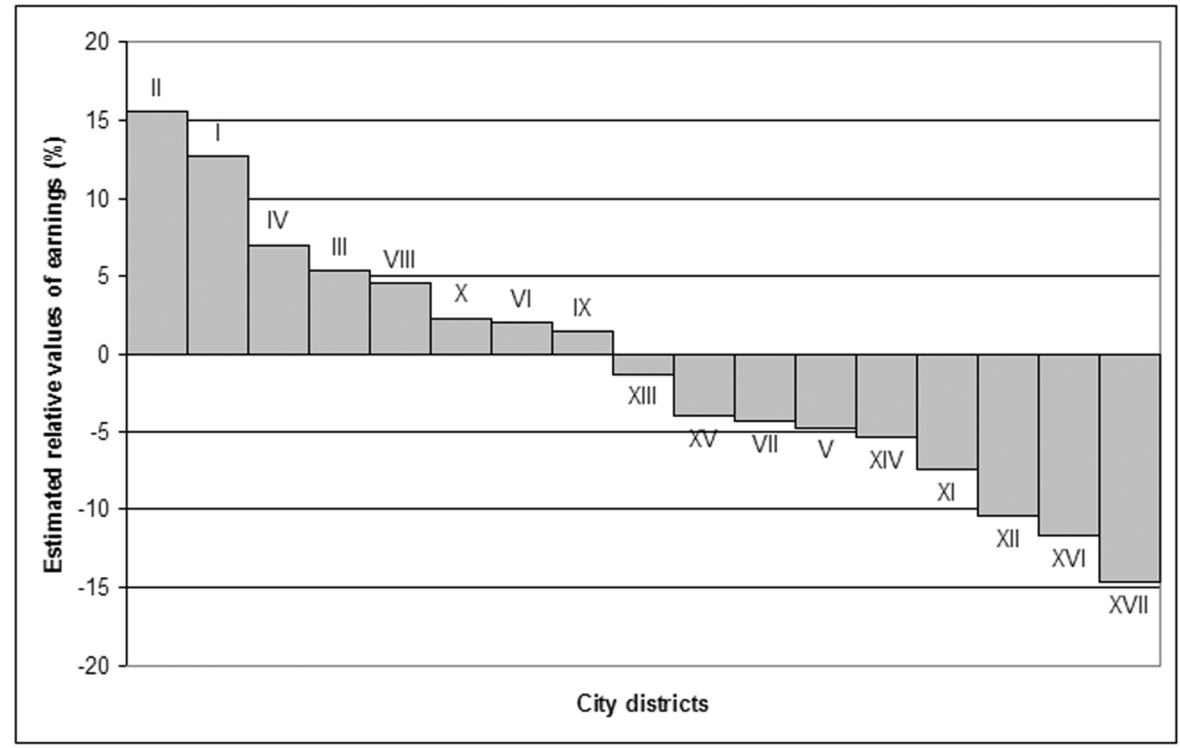

(I Donji grad, II Gornji grad-Medveščak, III Trnje, IV Maksimir, V Pečćenica-Žitnjak, VI Novi Zagrebistok, VII Novi Zagreb-zapad, VIII Trešnjevka-sjever, IX Trešnjevka-jug, X Črnomerc, XI Gornja Dubrava, XII Donja Dubrava, XIII Stenjevec, XIV Podused-Vrapče, XV Podsljeme, XVI Sesvete, XVII Brezovica)

Structure of employed according to economic sectors and unemployment. Important feature of postsocialist cities are changes in component of economic sectors and the increase of unemployment. With the transition from planned to a market economy the importance of manufacturing activities as well as the number of employed in manufacturing decreased. The changes didn't bypass the City of Zagreb. Already in 1981 Zagreb was tertiary city (Vresk; 1986) with around $60 \%$ of employed in services. This function was even more emphasized in the period of transition. The number of employed in manufacturing fell from $30 \%$ in 1981 to a little bit below $20 \%$ in 2001. Decrease in manufacturing was followed with a rise of unemployment. Significant influence on the rise of total unemployment, if not the most important, had processes of privatization and transition. The results of recent rese- 
arches (Bendeković, 2001; Lasić, 2001) have proved that existing way of privatization and transition has not fulfilled declared economic and social goals. Among the unfavou-rable impacts, the unemployment is certainly the most marked one.

In a period 1990-2000 the number of unemployed in City of Zagreb raised almost $135 \%$ ! Unemployment, especially the long-term unemployment, can have large impact on the socio-spatial structure. Parts of the city where that problem is very serious can be socially downgraded. The negative influence of unemployment is spread all over the City (Figure 4). Little bit below average are the central parts of the city, while in peripheral parts the rate is over $20 \%$. If we compare this date with previous two indicators of socioeconomic status it is clear that they have related pattern. Areas with the lowest rates of unemployment have better educational structure, higher earnings, and vice versa, those with the highest rates of unemployment have mentioned socioeconomic indicators at lower level.

Figure 4: Rates of unemployment in city districts of City of Zagreb in 2001

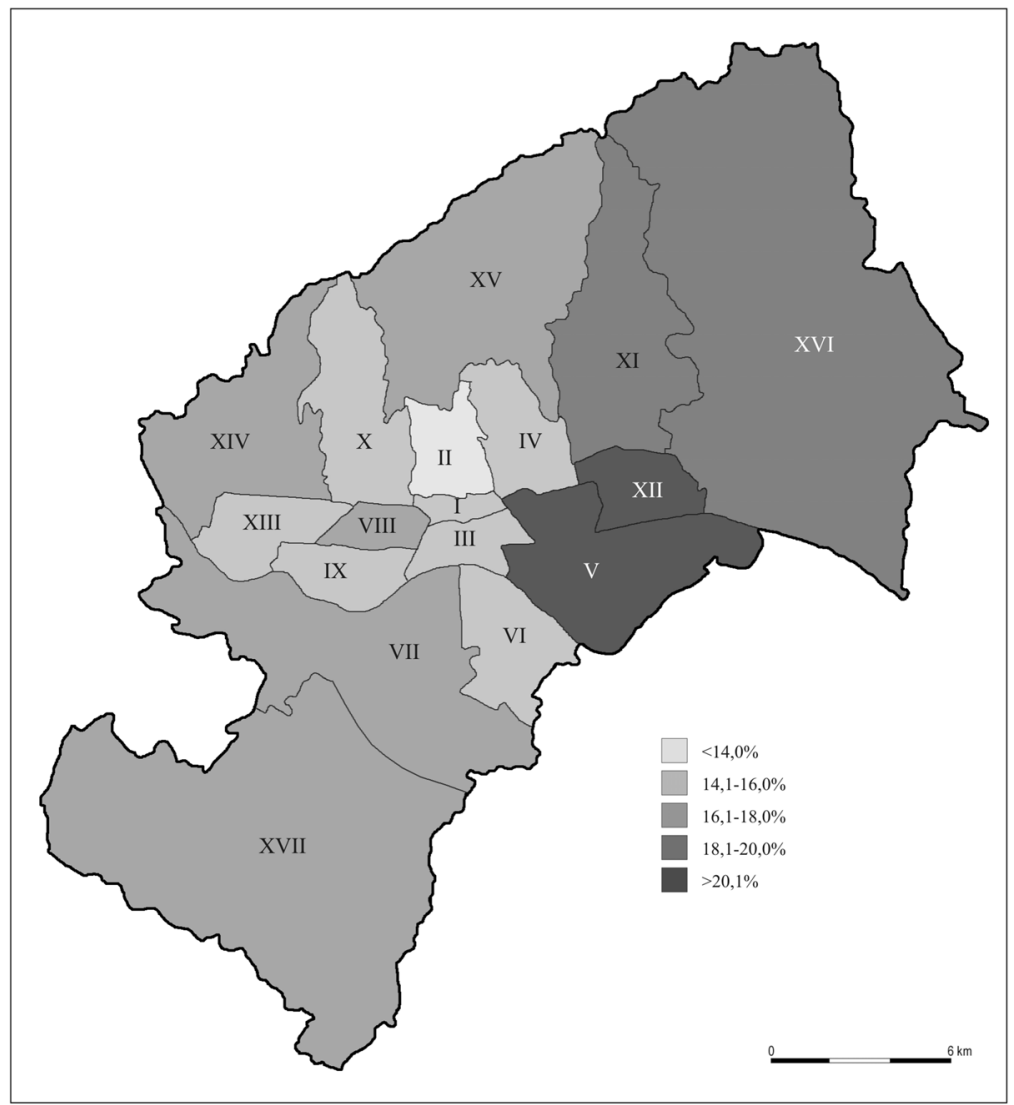

(I Donji grad, II Gornji grad-Medveščak, III Trnje, IV Maksimir, V Pečćenica-Žitnjak, VI Novi Zagrebistok, VII Novi Zagreb-zapad, VIII Trešnjevka-sjever, IX Trešnjevka-jug, X Črnomerc, XI Gornja Dubrava, XII Donja Dubrava, XIII Stenjevec, XIV Podused-Vrapče, XV Podsljeme, XVI Sesvete, XVII Brezovica) 


\section{CONCLUSION}

Despite the lack of relevant statistical indicators, preliminary results of analysis of the socio-spatial structure of the City of Zagreb show significant changes in relation to past period (before transition). The concentric pattern of the socio-spatial structure inherited from the period before transition is kept. Socioeconomic status of population is declining from the city centre to peripheral parts. Better situation, compared with previous period, is evident in educational structure. That kind of pattern is characteristic for other postsocialist cities in Central and Eastern Europe. Transition from market to planned economy had significant influence on the differences in average monthly earnings and on the rise of unemployment. These differences can be viewed as a beginning of a process of socio-spatial polarisation in Zagreb. On one side there are the city districts of the city centre and on the other side those in the peripheral parts. Between these two extremes are quarters with not so large aberration. These changes are related to those identified in the postsocialist cities.

\section{Literature}

Andersen, H. S., Andersen, H. T., Ærø, T., 2000: Social polarisation in a segmented housing market: Social segregation in Greater Copenhagen. Geografisk Tidsskrift, Danish Journal of Geography 100, 71-83.

Andersen, H. T., 2002: Globalisation, spatial polarization and the housing market. Geografisk Tidsskrift, Danish Journal of Geography 102, 93-102.

Badcock, B., 1997: Restructuring and spatial polarization in cities. Progress in Human Geography, 21, 251-262.

Bašić, K., 1994a: Socijalna topografija Zagreba - dihotomija grada i suburbija. Sociologija sela 32, 27-42.

Bašić, K., 1994b: Obiteljski status - aspekt socijalne topografije Zagreba. Geografski glasnik 56, 69-81.

Bendeković, J., 2001: Privatization in Croatia. Ekonomski pregled 51, 55-90.

Clark, W.A.V., McNicholas, M., 1996: Re-examing economic and social polarisation in multi-ethnic Metropolitan area: the case of Los Angeles. Area 28, 56-63.

Hamnett, C., 1998: Social Polarization and Inequality in Europe. Nederlandse Geographische Studies, 32-40.

Hamnett, C. 2001: Social Segregation and Social Polarization. V: Paddison, R. (editor), Handbook of Urban Studies, Sage, London, 162-176.

Hamnett, C., Cross, D., 1998: Social change, social polarisation and income inequality in London. 1979-1993, GeoJournal 46, 39-50.

Knox, P., Pinch, S., 2000: Urban Social Geography: An Introduction. Harlow, Prentice Hall.

Kostinskiy, G., 2001: Post-Socialist Cities in Flux. V: Paddison, R. (editor), Handbook of Urban Studies, Sage, London, 451-465.

Lasić, V., 2001: Koncept modela privatizacije u Hrvatskoj. Ekonomski pregled 51, 107117. 
Marinović-Uzelac, A., 1978: Socijalni prostor grada, Zagreb. Sveučilišna naklada Liber.

Rebernik, D., 2002: Socialnogeografska zgradba in preobrazba Ljubljane. V: Pak, M. (urednik): Geografija Ljubljane, Oddelek za geografijo Filozofske fakultete Univerze v Ljubljani, Ljubljana, 85-116.

Sassen, S., 2001: The Global City. New York, London, Tokyo. Princeton, Princeton Press.

Sykora, L., 1999: Processes of socio-spatial differentiation in post-communist Prague.Housing Studies, 14, 679-701.

Vresk, M. 1986: Neki pokazatelji funkcionalno-prostorne strukture Zagreba. Radovi 21.

Węcławowicz, G. 1997: The changing socio-spatial patterns in Polish cities. V: Kovacs, Z. Wießner, R. (Hrsg.): Prozesse und Perspektiven der Stadtentwicklung in Ostmitteleuropa, Münchner Geographische Hefte 76, Passau, 75-82.

Wießner, R. 1997: Sozialraumliche Polarisierung der inneren Stadt Budapest. V: Kovacs, Z, Wießner, R. (Hrsg.): Prozesse und Perspektiven der Stadtentwicklung in Ostmitteleuropa, Münchner Geographische Hefte 76, Passau, 189-202.

Woodward, R., 1995: Approaches towards the study of social polarization in the UK. Progress in Human Geography, 19, 75-89.

Statistical sources

Population census 1981

Population census 2001 CD-ROM

Statistical Yearbook of Zagreb 1991

Statistical Yearbook of City of Zagreb 2002 